\title{
Chapter 2 \\ Platform Work: Critical Assessment of Empirical Findings and its Implications for Social Security
}

\section{Olga Chesalina}

\section{Introduction}

The platform economy is characterised by platform work as a new form of employment. So far, no uniform definition of platform work has been established in the literature, in empirical studies or across European and international organisations. Nevertheless, there is a consensus concerning the division of platform work into two main types. Valerio de Stefano has proposed to distinguish between crowdwork and work on demand. ${ }^{1}$ Eurofound also follows this divison. ${ }^{2}$ Crowdwork is a form of employment that "uses an online platform to enable organizations or individuals to access an indefinite and unknown group of other organizations or individuals to solve specific problems or to provide specific services or products in exchange for payment". ${ }^{3}$ In the case of work on demand via apps the execution of specific services, such as transport, cleaning and running errands etc. is offered to an indefinite number of individuals by means of electronic platforms (app companies). ${ }^{4}$ Other terms for crowdwork are "location-

1 De Stefano, Valerio, The Rise of the "Just-in-Time Workforce": On-Demand Work, Crowdwork and Labour Protection in the "Gig-Economy", in: Conditions of Work and Employment Series, International Labour Office, Geneva, 71 (2016), https://w ww.ilo.org/travail/whatwedo/publications/WCMS_443267/lang--en/index.htm Accessed 12 September 2020.

2 Eurofound, Work on Demand: Recurrence, Effects and Challenges, Luxembourg: Publications Office of the European Union, 2018, doi:10.2806/463459, https:/ww w.eurofound.europa.eu/publications/report/2018/work-on-demand-recurrence-effe cts-and-challenges. Accessed 12 September 2020.

3 Eurofound, New Forms of Employment, Luxembourg: Publications Office of the European Union, 2015, doi:10.2806/937385, https:/www.eurofound.europa.eu/site s/default/files/ef_publication/field_ef_document/ef1461en.pdf. Accessed 12 September 2020.

4 De Stefano, Valerio, The Rise of the "Just-in-Time Workforce": On-Demand Work, Crowdwork and Labour Protection in the "Gig-Economy" (fn. 1). 
independent", web-based, ${ }^{5}$ online work, remote platform work $^{6}$; other terms for work on demand are offline work, on-location platform work (location-based). ${ }^{7}$

Labour law classification, working conditions and labour law protection for platform workers have already been the subject of numerous studies and publications, ${ }^{8}$ whereas social law research in this field is still in its infancy. Platform work has already been addressed in a wide range of sociological, economic and political studies. Nevertheless, questions regarding the social security of platform workers represent a very young field of research dealt with only in recent studies.

In studies, two approaches are used concerning the issue of access of platform workers to social protection: Firstly, there are various studies that exclusively target platform workers. ${ }^{9}$ An excellent example worth mentioning is the study for the EMPL Committee entitled "The Social Protection of

5 Pesole, Annarosa/Urzi Brancati, Maria Cesira/Fernández-Macías, Enrique/Biagi, Federico/González Vázquez, Ignacio, Platform Workers in Europe, EUR 29275 EN, Publications Office of the European Union, Luxembourg, 2018, ISBN 978-92-79-87996-8, doi:10.2760/742789, JRC112157, p. 14, https://publications.jrc.e c.europa.eu/repository/bitstream/JRC112157/jrc112157_pubsy_platform_workers_ in_europe_science_for_policy.pdf. Accessed 12 September 2020.

6 Piasna, Agnieszka, Counting Gigs. How Can we Measure the Scale of Online Platform Work? Working Paper 2020.06, ETUI, Brussels: ETUI aisbl, 2020, p. 11, https: //www.etui.org/sites/default/files/2020-09/Counting\%20gigs_2020_web.pdf. Accessed 12 September 2020.

7 Ibid.

8 Blanpain, Roger/Hendrickx, Frank/Waas, Bernd (eds.), New Forms of Employment in Europe, Alphen aan den Rijn: Wolters Kluwer 2016; Prassl, Jeremias, Humans as a Service, Oxford: Oxford University Press 2018; Meil, Pamela/Kirov, Vassil (eds.), Policy Implications of Virtual Work, Cham: Palgrave Macmillan 2017. In the handbook of Davidson, Nestor M./Finck, Michèle/Infranca, John J. (eds.), Cambridge Handbook of the Law of the Sharing Economy, Cambridge: Cambridge University Press 2018, the sharing economy is addressed from different legal perspectives, i. a. from the labour law perspective, but not from the social law perspective. Platform work as a kind of precarious work from the labour law perspective is devoted some contributions in Kenner, Jeff/Florczak, Izabela/Otto, Marta (eds.), Precarious Work. The Challenge for Labour Law in Europe, Cheltenham: Edward Elgar Publishing 2019.

9 Berg, Janine, Income Security in the On-Demand Economy: Findings and Policy Lessons from a Survey of Crowdworkers, in: Conditions of Work and Employment Series, International Labour Office, Geneva, 74 (2016); Digital Labour Platforms and the Future of Work: Towards Decent Work in the Online World, International Labour Office - Geneva, ILO, 2018, https:/www.ilo.org/wcmsp5/groups/public/--dgreports/---dcomm/---publ/documents/publication/wcms_645337.pdf. Accessed 12 September 2020; Eurofound, Employment and Working Conditions of 
Workers in the Platform Economy"10, which provides comprehensive research findings on the social protection of platform workers. Secondly to be mentioned are studies that analyse the situation of platform workers among a larger category of persons in non-standard forms of employment, ${ }^{11}$ new forms of work ${ }^{12}$ or among self-employed persons. ${ }^{13}$ The studies of the second group provide, in large part, insights from a social policy point of view rather than from empirical evidence. Many studies mention social security issues only briefly. ${ }^{14} \mathrm{~A}$ mix between the first and the second approach is the study of the European Social Insurance Platform entitled

Selected Types of Platform Work, Luxembourg: Publications Office of the European Union, 2018, https:/www.eurofound.europa.eu/sites/default/files/ef_publica tion/field_ef_document/ef18001en.pdf. Accessed 12 September 2020; Pesole, Annarosa/Urzí Brancati, Maria Cesira/Fernández-Macías, Enrique/Biagi, Federico/ González Vázquez, Ignacio, Platform Workers in Europe (fn. 5); Zachary, Kilhoffer/De Groen, Willem Pieter/Lenaerts, Karolien/Smits, Ine/Hauben, Harald/ Waeyaert, Willem/Giacumacatos, Elisa/Lhernould, Jean-Philippe/Robin-Olivier, Sophie, Study to Gather Evidence on the Working Conditions of Platform Workers, VT/2018/032, Final Report, 13 March 2020, European Commission, 2020.

10 Forde, Chris/Stuart, Mark/Simon, Joyce/Oliver, Liz/Valizade, Danat/Alberti, Gabriella/ Hardy, Kate/Trappmann, Vera/Umney, Charles/Carson, Calum, The Social Protection of Workers in the Platform Economy, Study for the EMPL Committee, European Union, Brussels, 2017, http:/www.europarl.europa.eu/RegData/etudes/STU D/2017/614184/IPOL_STU(2017)614184_EN.pdf. Accessed 12 September 2020.

11 Spasova, Slavina/Bouget, Denis/Ghailani, Dalila/Vanhercke, Bart, Access to Social Protection for People Working on Non-Standard Contracts and as Self-Employed in Europe. A Study of National Policies. European Social Policy Network (ESPN), Brussels: European Commission, 2017; OECD, The Future of Social Protection: What Works for Non-Standard Workers?, OECD Publishing, Paris, 2018, https://d oi.org/10.1787/9789264306943-en. Accessed 12 September 2020.

12 OECD, New Forms of Work in the Digital Economy, OECD Digital Economy Papers, No. 260, OECD Publishing, Paris, 2016, https://doi.org/10.1787/5jlwnklt8 20x-en. Accessed 12 September 2020; OECD, Policy Responses to New Forms of Work, OECD Publishing, Paris, 2019, https://doi.org/10.1787/0763f1b7-en. Accessed 12 September 2020.

13 ILO/OECD, Ensuring Better Social Protection for Self-Employed Workers, paper prepared for the 2nd Meeting of the G20 Employment Working Group under Saudi Arabia's presidency, 8 April 2020, https:/www.ilo.org/wcmsp5/groups/publ ic/---dgreports/---ddg_p/documents/publication/wcms_742290.pdf. Accessed 12 September 2020.

14 Pesole, Annarosa/Urzi Brancati, Maria Cesira/Fernández-Macías, Enrique/Biagi, Federico/González Vázquez, Ignacio, Platform Workers in Europe (fn. 5); Zachary, Kilhoffer/De Groen, Willem Pieter/Lenaerts, Karolien /Smits, Ine/Hauben, Harald/ Waeyaert, Willem/Giacumacatos, Elisa/Lhernould, Jean-Philippe/Robin-Olivier, Sophie, Study to Gather Evidence on the Working Conditions of Platform Workers (fn. 9); Digital Labour Platforms and the Future of Work: Towards Decent Work 
"Are Social Security Systems Adapted to New Forms of Work Created by Digital Platforms?" 15 . It is mainly based on a questionnaire sent out to social security institutions that made it possible "to provide a state-of-the-art view on the situation of platform workers and social security in certain countries"16. This study covers two main types of platform work (online delivered platform work and locally delivered work).

This chapter provides a critical assessment of empirical studies and practical findings. In this context, we would like to focus rather on cross-national studies (European or international perspective) than on national studies (however, in some cases we shall also refer to those). With this understanding, the author seeks to elaborate the implications for social security and some proposals for future investigations. The chapter is organised as follows: The following, second Section discusses the novelty of platform work in comparison to other forms of non-standard employment and the specifics of the business model of online labour platforms. The third Section considers the size of platform work and issues concerning cross-border labour flows in platform work, reflecting the shortcomings of empirical studies. Implications for social security resulting from empirical findings are examined in the fourth Section. Hereby, the motivation of platform workers and their access to social protection as well as dependence patterns are analysed. Special attention is paid to comparing the situation of platform workers concerning access to social protection to that of nonstandard workers and self-employed persons. The implications for social security from practical evidence are discussed in the fifth Section. Finally, and important from a social security point of view, shortcomings of empirical and practical evidence are summarised and proposals for future investigations are offered.

in the Online World (fn. 9); Eurofound, Employment and Working Conditions of Selected Types of Platform Work (fn. 9); Florisson, Rebecca/Mandl, Irene, Platform Work: Types and Implications for Work and Employment - Literature Review, Working Paper WPEF18004, Eurofound, Dublin, 2018, https://www.eurofo und.europa.eu/sites/default/files/wpef18004.pdf. Accessed 12 September 2020.

15 ESIP, Are Social Security Systems Adapted to New Forms of Work Created by Digital Platforms?, 30 January 2019, https://esip.eu/images/pdf_docs/ESIP_Study_ Platform_Work.pdf. Accessed 12 September 2020.

16 Ibid., p. 4 . 


\section{Platform Work: What is Really New?}

There is an ongoing discussion on whether platform work is something entirely new or rather a result of the evolutionary development of work organisation. ${ }^{17}$ The supporters of the first approach consider platform work as the "most relevant manifestation of new forms of employment generated by technological change" 18 , "a new way to share and exchange goods, services and knowledge" 19 . This group (which includes platform providers themselves) considers technology to be a driving force. ${ }^{20}$ However, numerous researchers are sceptical about the leading role of technology behind the growth of the platform economy. Research has shown that it is not technology, but taxes, social contributions and other cost-savings that are key drivers of the expansion of platform work. Some research sees an interrelationship between the decline of standard employment relationships and the emergence and proliferation of platform work. ${ }^{21}$

Platform work reflects a number of different trends on the labour market over several decades ${ }^{22}$ : fragmentation, segmentation and precariousness of work, ${ }^{23}$ commodification of labour, control mechanisms of economic partners via telecommunication tools, disruption of the concept of firm, bogus self-employment, shift of risks from the employer to the employee

17 Stanford, Jim, The Resurgence of Gig Work: Historical and Theoretical Perspectives, in: Economic and Labour Relations Review, 28 (2017) 3, pp. 382-401, https:/ /doi.org/10.1177/1035304617724303. Accessed 12 September 2020.

18 Royo, Miguel Rodríguez-Piñero, Spain, in: Daugareilh, Isabelle/Degryse, Christophe/Pochet, Philippe (eds.), The Platform Economy and Social Law: Key Issues in Comparative Perspective, ETUI Working Paper 2019.10, Brussels, 2019, p. 92 f., https://www.etui.org/Publications2/Working-Papers/The-platform-econo my-and-social-law-Key-issues-in-comparative-perspective. Accessed 12 September 2020.

19 Semenza, Renata/Mori, Anna, New Self-Employment as a Theoretical Matter, in: Semenza, Renata/Pichault, François (eds.), The Challenges of Self-Employment in Europe. Status, Social Protection and Collective Representation, Cheltenham: Edward Elgar 2019, p. 27.

20 Joyce, Simon/Stuart, Mark/Forde, Chris/Valizade, Danat, Work and Social Protection in the Platform Economy in Europe, p. 14, http://eprints.whiterose.ac.uk/148824/. Accessed 12 September 2020.

21 Ibid., p. 3.

22 Huws, Ursula, Where did Online Platforms Come From? The Virtualization of Work Organization and the New Policy Challenges it Raises, in: Meil, Pamela/ Kirov, Vassil (eds.), Policy Implications of Virtual Work, Cham: Palgrave Macmillan 2017, pp. 30-31.

23 Joyce, Simon/Stuart, Mark/Forde, Chris/Valizade, Danat, Work and Social Protection in the Platform Economy in Europe (fn. 20), p. 14. 
and spread of self-employment and informal work. For this reason, some research does not consider the challenges presented by platform employment as something new in comparison to challenges posed by non-standard employment and self-employment. ${ }^{24}$ This has been confirmed by a recent study of the European Commission. ${ }^{25}$

Digital technologies are one of the factors that contributed to the emergence of platform work. At the same time, digital technologies have significant consequences for the development of platform work: they enable virtual ${ }^{26}$ connections between all participants of this business construction ("digital intermediation"27), they allow platforms to control platform workers permanently and to avoid employment law classification. These digital mechanisms were not known and used before. The proliferation of crowdwork in a certain country depends on the respective level of internet availability. Summarising all the above, we consider that all mentioned factors together called platform work as a new form of employment into existence.

Platform work is the outcome of a business model of labour platform companies. Natalie Munkholm argues in this book that platform companies represent a new form of company model rather than new forms of work. ${ }^{28}$ In our opinion, we cannot separate a new form of business model from a new form of employment: they are both new as they are interconnected. Even if there is a variety of labour platforms, the assessment of academic literature and empirical findings allows us to highlight the following distinctive features of this business model:

24 Garben, Sacha, Tackling Social Disruption in the Online Platform Economy. Shifting the Narrative to the Benefits of (EU) Regulation, FEPS Policy Paper, July 2019 , p. 7, https://www.feps-europe.eu/attachments/publications/feps\%20paper\% 20-\%20garben\%20-\%20clean\%20final.pdf. Accessed 12 September 2020.

25 Zachary, Kilhoffer/Pieter De Groen, Willem/Lenaerts, Karolien/Smits, Ine/Hauben, Harald/Waeyaert, Willem/Giacumacatos, Elisa/Lhernould, Jean-Philippe/Robin-Olivier, Sophie, Study to Gather Evidence on the Working Conditions of Platform Workers (fn. 9), p. 226.

26 Ursula Huws speaks about the "virtualization of work and virtualization of work organization", cf. Huws, Ursula, Where did Online Platforms Come From? The Virtualization of Work Organization and the New Policy Challenges it Raises (fn. 22), pp. 30-31.

27 Stanford, Jim, The Resurgence of Gig Work: Historical and Theoretical Perspectives (fn. 17), p. 384.

28 Munkholm,Natalie Videbak, Collective Agreements and Social Security Protection for Non-Standard Workers and Particularly for Platform Workers: The Danish Experience, Chapter 7, Section IV, p. 200 in this book. 
- There is a remarkable change in the structure of firms. Whereas the managerial firm is organised as an entity, platforms establish "hybrid governance structures". ${ }^{29}$ As market organisations they outsource work and shift risks to platform workers. ${ }^{30}$ While platforms try to possess few assets, ${ }^{31}$ the "new" class of the self-employed ${ }^{32}$ that has emerged through this business model often possesses some capital (e.g. car, flat) and are, at the same time, deprived of entrepreneurial freedom..$^{33}$

- Platform companies pretend to be a mere marketplace and an intermediary, with the result that platform workers are considered to be selfemployed.

- Platform companies (and also clients) try to avoid or limit labour and social responsibility ${ }^{34}$ as well as a classification of platform workers as employees or as employee-like persons. ${ }^{35}$

- Digital and informational technologies are an integral part of this business model.

- Platforms advertise this form of employment with workers' autonomy and flexible working arrangements. In fact, they are "controlling autonomy" 36 in the way that platform workers are controlled through algorithms and also human management.

29 Acquier, Aurélien, Uberization Meets Organizational Theory. Platform Capitalism and the Rebirth of the Putting-Out System, in: Davidson, Nestor M./Finck, Michèle/Infranca, John J. (eds.), Cambridge Handbook of the Law of the Sharing Economy, Cambridge: Cambridge University Press 2018, p. 15.

30 Ibid., pp. 15, 19.

31 Nick Srnicek has proposed to call "Uber's business model" a "lean platform", cf. Sniercek, Nick, Two Myths About the Future of the Economy, in: Skidelsky, Robert/Craig, Nan (eds.), Work in the Future. The Automation Revolution, Cham: Springer VS 2020, p. 134.

32 Lobel, Orly, Coase and the Platform Economy, in: Davidson, Nestor M./Finck, Michèle, Infranca, John J. (eds.), Cambridge Handbook of the Law of the Sharing Economy, Cambridge: Cambridge University Press 2018, p. 72.

33 Acquier, Aurélien, Uberization Meets Organizational Theory. Platform Capitalism and the Rebirth of the Putting-Out System (fn. 29), pp. 15, 19.

34 Desbarats, Isabelle, Workers in Legally Constituted Online Platforms in France: Should the Courts Determine Their Professional Categorization?, in: Revue de Droit Comparé du Travail et de la Sécurité Sociale - English Electronic Edition (2019) 4, p. 165.

35 Hotvedt, Marianne, The Contract-of-Employment Test Renewed. A Scandinavian Approach to Platform Work, in: Spanish Labour Law and Employment Relations Journal, 7 (2018) 1-2, p. 59, doi: https://doi.org/10.20318/sllerj.2018.4436.

36 Ivanova, Mirela/Bronowicka, Joanna/Kocher, Eva/Degner, Anne, The App as a Boss? Control and Autonomy in Application-Based Management. Arbeit/Grenze/Fluss - Work in Progress interdisziplinärer Arbeitsforschung No. 2, Frankfurt (Oder): 
- Control through algorithmic methods (including rating systems) and financial incentives prevail over control through "classical labour law tools". Nevertheless, there is a covert subordination.

- The relationship between the platform and the platform worker is characterised by information asymmetries. ${ }^{37}$ Platforms gather a huge amount of data concerning platform workers and, simultaneously, this information is withheld from platform workers. ${ }^{38}$ This gives labour platforms greater power over workers.

- Platforms introduce recommendation systems based on data collected from workers in order to encourage them to adopt a certain targeted behaviour.

- Platforms purposely use the "overstaffing" strategy: regarding work via platforms, the number of active drivers, couriers or other platform workers registered with the platform is many times higher than would be necessary for the fulfilment of all orders during a certain period of time or during a shift. ${ }^{39}$

Platform workers are highly substitutable and impersonalised. An extreme commodification of labour is happening.

While some courts have already recognised the new forms of control and monitoring mechanisms (and in particularly, geolocation) as features of employment relationship, ${ }^{40}$ others have refused to do so. For example, in the first German labour law judgement concerning the employment classification of a platform worker, the courts of first and of second instance have refused to recognise his employee status. ${ }^{41}$ It remains to be seen whether the Federal Labour Court ${ }^{42}$ will recognise that the platform worker was practically, economically and personally dependent on the platform, including through the use of its monitoring mechanisms.

Viadrina, 2018, doi: 10.11584/Arbeit-Grenze-Fluss.2.; Schönefeld, Daniel, Kontrollierte Autonomie. Einblick in die Praxis des Crowdworking, in: Hensel, Isabell/ Schönefeld, Daniel/Kocher, Eva/Schwarz, Anna/Koch, Jochen (eds.), Selbständige Unselbständigkeit, Baden-Baden: Nomos 2019, p. 76.

37 Ivanova, Mirela/Bronowicka, Joanna/Kocher, Eva/Degner, Anne, The App as a Boss? Control and Autonomy in Application-Based Management (fn. 36), p. 16.

38 Ibid., p. 16.

39 Ibid., p. 7.

40 E. g. in France the decision of the Labour Chamber of the Supreme Court of 28 November No. 17-20.079.

41 Decision of the Labour Court of Second Instance of Munich of 4 December 2019 - 8 Sa146/19.

42 The proceeding is scheduled for 1 December 2020. 
The business model of labour platforms is highly changeable. The numerous court decisions in favour of the employee or worker status of platform workers prompt platforms to change their initial strategy and find new ways to avoid the application of compulsory labour and social law regulations. ${ }^{43}$

In fact, platform work is a highly heterogeneous category. Some platform workers are genuinely self-employed persons, i.e. professional selfemployed workers. This group is the main beneficiary and sees platform work as an opportunity. ${ }^{44}$ Simultaneously, the situation of other platform workers is even more precarious than that of workers in other non-standard forms of employment. ${ }^{45}$

\section{Empirical Evidence}

\section{Situation at a Glance}

Since the emergence of platform-mediated work, there have been a lot of attempts to estimate and evaluate this phenomenon. Today, there are already a number of studies and surveys that give insights into platform work. The estimations on the size of the platform economy vary significantly across the studies because of different research methodologies and different definitions of platform work used. ${ }^{46}$ Different studies indicate

43 The most recent example being Uber, which has changed its app after the law "AB5" came into effect in order to avoid drivers operating as contractors to be classified as employees. In particular, it allowed drivers to set their own rates. Cf. Paul, Kari, Uber and Lyft must classify drivers as employees, judge rules, in blow to gig economy, The Guardian, 10 August 2020, https:/www.theguardian.com/te chnology/2020/aug/10/uber-lyft-ruling-california-judge. Accessed 12 September 2020; other examples are mentioned by Zachary, Kilhoffer/De Groen, Willem Pieter/ Lenaerts, Karolien/Smits, Ine/Hauben, Harald/Waeyaert, Willem/Giacumacatos, Elisa/ Lhernould, Jean-Philippe/Robin-Olivier, Sophie, Study to Gather Evidence on the Working Conditions of Platform Workers (fn. 9), p. 122.

44 Semenza, Renata/Mori, Anna, New Self-Employment as a Theoretical Matter (fn. 19), p. 28.

45 Some scholars consider platform work as a last stage of precariousness. See Cavallini, Gionata/Avogaro, Matteo, "Digital Work" in the "Platform Economy": The Last (but not Least) Stage of Precariousness in Labour Relationships, in: Kenner, Jeff/Florczak, Izabela/Otto, Marta (eds.), Precarious Work. The Challenge for Labour Law in Europe, Cheltenham: Edward Elgar Publishing 2019, p. 176.

46 Zachary, Kilhoffer/De Groen, Willem Pieter/Lenaerts, Karolien/Smits, Ine/Hauben, Harald/Waeyaert, Willem/Giacumacatos, Elisa/Lhernould, Jean-Philippe/Robin-Olivi- 
that between one and five percent of the working age population are somehow engaged in platform work. ${ }^{47}$ While one group of studies shows that the rise of work on demand (offline platform work) is significantly higher than that of crowdwork ${ }^{48}$ other studies come to the opposite result. ${ }^{49}$

Many studies demonstrate that platform work is "an emerging phenomenon of increasing importance but still modest in size" 50 . There are different scenarios and estimations concerning the growth of platform work, as to whether it has already peaked or continues to extend. According to one approach, confirmed in some more recent studies, the number of platform workers has dropped. ${ }^{51}$ According to a different approach,

er, Sophie, Study to Gather Evidence on the Working Conditions of Platform Workers (fn. 9), pp. 44-45.

47 ESIP, Are Social Security Systems Adapted to New Forms of Work Created by Digital Platforms? (fn. 15), p. 4; Forde, Chris/Stuart, Mark/Simon, Joyce/Oliver, Liz/ Valizade, Danat/Alberti, Gabriella/Hardy, Kate/Trappmann, Vera/Umney, Charles/ Carson, Calum, The Social Protection of Workers in the Platform Economy ( $\mathrm{fn}$. 10); OECD, Measuring Platform Mediated Workers, OECD Digital Economy Papers, No. 282, OECD Publishing, Paris, 2019, pp. 8-12, https://doi.org/10.1787/17 0a14d9-en. Accessed 12 September 2020; Zachary, Kilhoffer/De Groen, Willem Pieter/Lenaerts, Karolien /Smits, Ine/Hauben, Harald/ Waeyaert, Willem/ Giacumacatos, Elisa/Lhernould, Jean-Philippe/Robin-Olivier, Sophie, Study to Gather Evidence on the Working Conditions of Platform Workers (fn. 9), p. 44; Freudenberg, Christoph, Rising Platform Work. Scope, Insurance Coverage and Good Practices among ISSA Countries, German Federal Pension Insurance/Technical Commission on Old-Age, Invalidity and Survivors Insurance, World Social Security Forum, Brussels, 14-18 October 2019, p. 1.

48 Drahokoupil, Jan/Fabo, Brian, The Platform Economy and the Disruption of the Employment Relationship. ETUI Policy Brief, Brussels, 2016, http://www.etui.org /Publications2/Policy-Briefs/European-Economic-Employment-and-Social-Policy/ Collective-labour-law-under-attack-how-anti-crisis-measures-dismantle-workers-col lective-rights. Accessed 12 September 2020.

49 Zachary, Kilhoffer/De Groen, Willem Pieter/Lenaerts, Karolien/Smits, Ine/Hauben, Harald/Waeyaert, Willem/Giacumacatos, Elisa/Lhernould, Jean-Philippe/Robin-Olivier, Sophie, Study to Gather Evidence on the Working Conditions of Platform Workers (fn. 9), p. 228; ILO/OECD, Ensuring Better Social Protection for SelfEmployed Workers (fn. 13), p. 4.

50 Pesole, Annarosa/Urzi Brancati, Maria Cesira/Fernández-Macías, Enrique/Biagi, Federico/González Vázquez, Ignacio, Platform Workers in Europe (fn. 5), p. 5.

51 ILO/OECD, Ensuring Better Social Protection for Self-Employed Workers (fn. 13); Urzí Brancati, Maria Cesira/Pesole, Annarosa/Fernandez Macias, Enrique, New Evidence on Platform Workers in Europe, EUR 29958 EN, Publications Office of the European Union, Luxembourg, 2020, ISBN 978-92-76-12949-3 (online), doi:10.2760/459278 (online), JRC118570, p. 4. 
platform work will continue to extend..$^{52}$ It is important to recall that platform work and labour platforms like TaskRabbit and Uber emerged and have grown after the global financial crisis of 2007.53 The global coronavirus crisis of 2020, which is accompanied by job losses and a deep economic recession, will most likely contribute to the further growth of certain types of platform work and the emergence of new, as yet unknown forms of non-standard work. There is first evidence of such a development, e.g. the number of new registrations on the freelancer platform PeoplePerHour increased in March 2020: in the UK, registrations rose by 300 percent, in Spain by 329 percent and in Japan by as much as 513 percent. ${ }^{54}$

\section{Shortcomings of Empirical Studies}

The studies available up to now provide a lot of information about the socio-demographic characteristics of platform workers, their working conditions, access to labour and social protection. However, there are considerable limitations to the studies and the data:

(1) There is a lack of reliable data on platform work..$^{55}$ Official data is almost non-existent. Until 2016/2017, there was no official statistical data on the total number of platform workers at all, and until now only some countries have such data. One of the first large-scale official statistical data concerning electronically mediated employment (in-person, offline tasks and online task) was presented in the survey of the American Bureau of Labor Statistics (BLS) of May 2017.56 It was found that one percent of the total employed population in the US were en-

52 Huws, Ursula, Where did Online Platforms Come From? The Virtualization of Work Organization and the New Policy Challenges it Raises (fn. 22).

53 Ibid., p. 29.

54 The Coronavirus Crisis is Shining a Light on the Difficult Situation Many Gig Workers Face, 8 April 2020, https://www.rolandberger.com/en/Point-of-View/The -future-of-the-gig-economy.html. Accessed 12 September 2020; Achleitner, Ranjana Andrea, Plattformbasierte Arbeit als Herausforderung der EU - Handlungsperspektiven und aktuelle Initiativen der Union, in: ZESAR, (2020) 9, p. 363.

55 Zachary, Kilhoffer/De Groen, Willem Pieter/Lenaerts, Karolien/Smits, Ine/Hauben, Harald/Waeyaert, Willem/Giacumacatos, Elisa/Lhernould, Jean-Philippe/Robin-Olivier, Sophie, Study to Gather Evidence on the Working Conditions of Platform Workers (fn. 9), p. 229.

56 U. S. Bureau of Labor Statistics, Labor Force Statistics from the Current Population Survey, Electronically Mediated Employment, https://www.bls.gov/cps/electr onically-mediated-employment.htm. Accessed 12 September 2020. 
gaged in this form of employment. More recently, some official statistical agencies of OECD member states have formulated questions on platform work in labour force surveys ${ }^{57}$ and Internet usage surveys. ${ }^{58}$

(2) There are more studies on crowdwork than on work on demand, as crowdworkers can be reached more easily by online surveys. ${ }^{59}$ Also problematic is the fact that the earliest research is based mostly on an analysis of the Amazon Mechanical Turk (AMT) platform, which means that a significant part of the current scientific knowledge refers to US-American employees. ${ }^{60}$

(3) Often the samples sizes of empirical studies are too small to make clear conclusions about platform workers' characteristics. ${ }^{61}$

(4) Some studies do not differentiate between types of platform work (online and offline platform work), or between work for one platform or work for many platforms.

(5) Studies show that there are considerable differences in the numbers of platform workers both across countries and across studies for the same country. ${ }^{62}$ Different factors may explain this situation:

- the high volatility of platform workers should be taken into account;

- $\quad$ some studies include - apart from activities on labour platforms also activities on capital platforms like Airbnb;

- $\quad$ some studies count all registered users ${ }^{63}$ while other studies count only active users, ${ }^{64}$ giving a more accurate picture of this phenomenon;

57 E.g. Finland extended the Labour Force Survey with questions on platform work in 2017, cf. Piasna, Agnieszka, Counting Gigs. How Can we Measure the Scale of Online Platform Work? (fn. 6), p. 12.

58 OECD, Measuring the Digital Transformation: A Roadmap for the Future, OECD Publishing, Paris, 2019, p. 176, https://doi.org/10.1787/9789264311992-en. Accessed 12 September 2020.

59 Joyce, Simon/Stuart, Mark/Forde, Chris/Valizade, Danat, Work and Social Protection in the Platform Economy in Europe (fn. 20), pp. 5, 14.

60 BMAS, Plattformbasierte Erwerbsarbeit: Stand der empirischen Forschung, Forschungsbericht No. 498, 2017, p. 44.

61 OECD, Measuring Platform Mediated Workers (fn. 47), p. 4.

62 OECD, Measuring Platform Mediated Workers (fn. 47), pp. 8-11; OECD, Measuring the Digital Transformation: A Roadmap for the Future (fn. 58), p. 176.

63 ESIP, Are Social Security Systems Adapted to New Forms of Work Created by Digital Platforms? (fn. 15), p. 21.

64 Piasna, Agnieszka, Counting Gigs. How Can we Measure the Scale of Online Platform Work? (fn. 6), p. 6. 
- there is no consistency in the definitions of platform work used in studies: while some studies use a broad definition of platform work, others use a rather narrow definition;

- many studies are not comparable as they cover different countries, use different definitions of platform work or online platforms, and examine different reference periods. ${ }^{65}$

(6) There are concerns in relation to the reliability of the studies. Relying on the outcome of studies concerning the classification of platform workers may lead to an inaccurate picture when the studies are based on the subjective opinion of the respondents. Many respondents misunderstand the questions and misinterpret the definitions of platform work ${ }^{66}$ and "online platforms" 67 used in a survey. For example, in the COLLEEM I survey, the majority of platform workers (68.1 percent) define themselves as employees, but de facto they are self-employed. ${ }^{68}$ There were different reasons for misinterpretations in this study, be it that the main activity of one respondent was in dependent employment, or that one respondent considered himself as an employee, or simply due to poor answer content. ${ }^{69}$

(7) While some studies cover platform work as a main job only when a substantial part of income is generated from it, others use a broader definition of platform work including cases where platform work is performed as a secondary job. ${ }^{70}$ Also some of the existing official labour statistics of the OECD member states (e.g. France) ${ }^{71}$ focus on a worker's primary job and can be unreliable in their coverage of secondary jobs and self-employment. ${ }^{72}$ Researchers stress that official labour market statistics are generally not suited for capturing sporadic or secondary employment. ${ }^{73}$ Using a longer reference period increases

65 Urzi Brancati, Maria Cesira/Pesole, Annarosa/Fernandez Macias, Enrique, New Evidence on Platform Workers in Europe (fn. 51), p. 11.

66 OECD, Measuring the Digital Transformation: A Roadmap for the Future (fn. 58), p. 176.

67 Piasna, Agnieszka, Counting Gigs. How Can we Measure the Scale of Online Platform Work? (fn. 6), p. 10.

68 Pesole, Annarosal Urzi Brancati, Maria Cesira/Fernández-Macías, Enrique/Biagi, Federico/González Vázquez, Ignacio, Platform Workers in Europe (fn. 5), p. 31.

69 Ibid.

70 OECD, Measuring Platform Mediated Workers (fn. 47), p. 8.

71 Ibid., p. 19.

72 Ibid., p. 14.

73 Piasna, Agnieszka, Counting Gigs. How Can we Measure the Scale of Online Platform Work? (fn. 6), p. 5. 
the share of occasional platform workers in the estimated number of platform workers. ${ }^{74}$

(8) Platform work is often informal or not precisely regulated, which might lead to an underestimation of the real dimension of the platform economy. ${ }^{75}$ However, there is a lack of statistical and empirical data on the prevalence of undeclared platform work. ${ }^{76}$

\section{Cross-Border Labour Flows in Platform Work}

The use of online labour platforms to access the global market is historically older than national labour platforms. For example, AMT was founded already in $2005 .{ }^{77}$ Online crowdsourcing platforms can be seen as a further step in the development of "global sourcing" of value chains. ${ }^{78}$

There are different forms of cross-border online platform work. A platform worker can perform work in one (home or other) country or more countries - while the client, platform or both can be located in another (EU or third) country or countries. The more platforms and/or clients, the more complicated constellations are possible. ${ }^{79}$ In the case of crowdwork, platforms and clients can always select a country which does not provide for any limitations or obstacles to platform work or which has not established any labour and social guarantees for platform workers. Mark Graham and Mohammad Amir Anwar write about a so-called "planetary labour market" in digital work ${ }^{80}$, where "clients can choose who they work

74 OECD, Measuring Platform Mediated Workers (fn. 47), p. 19.

75 Zachary, Kilhoffer/De Groen, Willem Pieter/Lenaerts, Karolien/Smits, Ine/Hauben, Harald/Waeyaert, Willem/Giacumacatos, Elisa/Lhernould, Jean-Philippe/Robin-Olivier, Sophie, Study to Gather Evidence on the Working Conditions of Platform Workers (fn. 9), p. 93.

76 Ibid.

77 Huws, Ursula, Where did Online Platforms Come From? The Virtualization of Work Organization and the New Policy Challenges it Raises (fn. 22), p. 30.

78 Ibid., p. 34.

79 Zachary, Kilhoffer/De Groen, Willem Pieter/Lenaerts, Karolien/Smits, Ine/Hauben, Harald/Waeyaert, Willem/Giacumacatos, Elisa/Lhernould, Jean-Philippe/Robin-Olivier, Sophie, Study to Gather Evidence on the Working Conditions of Platform Workers (fn. 9), p. 94.

80 Graham, Mark/Anwar, Mohammad Amir, The Global Gig Economy: Towards a Planetary Labour Market?, in: First Monday, 24 (2019) 4, DOI: https://doi.org/10. 5210/fm.v24i4.9913. Accessed 12 September 2020. 
with, among a larger pool of people from around the globe". ${ }^{81}$ According to Mark Graham and Mohammad Amir Anwar, a planetary market does not eliminate geography, but rather takes advantage of it. ${ }^{82}$ Furthermore, platforms profit from the huge over-supply of labour that pushes down labour costs and restricts the ability of workers to bargain for better conditions, ${ }^{83}$ including social security benefits. Klaus Schwab stresses that in these cases, the relocation of work to foreign countries happens invisibly. ${ }^{84}$ Researchers speak of "virtual migration", which occurs without the spatial movement of the body across borders but facilitates new forms of the global division of labour. ${ }^{85}$

In order to properly assess the need for transnational regulation and coordination of social security and the required level and type of regulation (e.g. at the international, European or regional level; in bilateral or international agreements; or with a view to recommendations or directives at the European level), it is necessary to have a clear picture about online platform labour flows, where clients (customers), platforms and platform workers are located in different countries respectively. At the moment, we only have a fragmented picture about cross-border labour flows related to on-demand platforms ("real migration") as well as to crowdwork (referred to as "virtual migration"). Furthermore, there is only limited data available on the prevalence of cross-border platform work. ${ }^{86}$

Despite the huge gaps in information about cross-border labour flows, we can note several trends. First, the younger a platform, the more local is its character (local clients, local platform workers). The longer-established platforms have a broader spread of nationalities. Among the platform workers registered with the German platform "Clickworker", for instance, about one third are from Germany, one third are from other European

81 Ibid.

82 Ibid.

83 Graham, Mark/Anwar, Mohammad Amir, Labour, in: Ash, James/Kitchin, Rob/ Leszczynski, Agnieszka (eds.), Digital Geographies, Los Angeles: Sage 2018.

84 Schwab, Klaus, Die Vierte Industrielle Revolution, München: Pantheon Verlag 2016, p. 75.

85 Website of the project Digitalisation of Labour and Migration. Berliner Institut für empirische Integrations- und Migrationsforschung, http://www.platform-mob ilities.net/en/konzepte-notizen. Accessed 12 September 2020.

86 Zachary, Kilhoffer/De Groen, Willem Pieter/Lenaerts, Karolien /Smits, Ine/Hauben, Harald/Waeyaert, Willem/Giacumacatos, Elisa/Lhernould, Jean-Philippe/Robin-Olivier, Sophie, Study to Gather Evidence on the Working Conditions of Platform Workers (fn. 9), p. 94. 
countries, and the remaining third are from the Americas. ${ }^{87}$ According to its own figures, the platform "Upwork" counts eight million crowdworkers from 180 countries. ${ }^{88}$ Second, language constraints dictate regional boundaries; for example, clients and platform workers speaking German are distributed, in addition to Germany, also across Switzerland and Austria. At the same time, access to certain global work platforms for non-native language speakers is likely to be associated with higher levels of educational attainment, even if the work carried out does not itself require high levels of education. ${ }^{89}$

\section{Implications for Social Security in Empirical Studies}

\section{Platform Work as a Main Job and as a Side Job, and Motivation of Platform Workers}

There is interesting evidence that studies consider as a "main job" not work for one single platform, but platform work as a kind of work/job itself. Such an approach is typical of studies exploring self-employment, which demonstrate the distribution of the self-employed across economic sectors.

All existing studies devoted to platform work come to the result that platform work is mainly (to an extent of approximately 70 percent) carried out as a side job in addition to a second or multiple jobs. This confirms studies covering only crowdwork which have shown that for about one third of crowdworkers, platform work was the main source of income. For example, the ILO study of 2018 shows that for 32 percent of crowdworkers platform work was the main source of income. ${ }^{90}$ The majority of platform

87 Eurofound, New Forms of Employment, Publications Office of the European Union (fn. 3), pp. 112-113.

88 Däubler, Wolfgang, Herausforderungen für das Arbeitsrecht - Deregulierung, Globalisierung, Digitalisierung, in: Arbeit und Recht, (2016) 8-9, p. 333.

89 Forde, Chris/Stuart, Mark/Simon, Joyce/Oliver, Liz/Valizade, Danat/Alberti, Gabriellal Hardy, Kate/Trappmann, Vera/Umney, Charles/Carson, Calum, The Social Protection of Workers in the Platform Economy (fn. 10), p. 31.

90 Digital Labour Platforms and the Future of Work: Towards Decent Work in the Online World (fn. 9), p. 41. 
workers provide more than one type of service and are active on two or more platforms. ${ }^{91}$

In order to analyse the need for social protection, it is important to consider the reasons for working in the platform economy, and whether such activity is chosen voluntarily or due to insufficient alternatives on the labour market. Numerous studies have shown the following:

(1) The most common reason for being a platform worker is the flexibility in working arrangements, working time and location. ${ }^{92}$

(2) Another important reason is the opportunity to earn an additional income..$^{93}$

(3) For some categories of workers, it is the only option on the labour market, e.g. for foreign workers. The studies confirm that foreign-born workers are significantly more likely to provide services via digital labour platforms than native workers. ${ }^{94}$ For example, a study of 2017 on Finland states that 70-80 percent of all food couriers were immigrants. ${ }^{95}$ The first large-scale statistical data on the share of migrant workers was presented in the survey of the BLS of May 2017 concerning electronically mediated employment. ${ }^{96}$

(4) Other categories who are interested in platform work are persons with disabilities and women with family obligations as they can only work

91 Pesole, Annarosa/Urzí Brancati, Maria Cesira/Fernández-Macías, Enrique/Biagi, Federico/González Vázquez, Ignacio, Platform Workers in Europe (fn. 5), p. 4.

92 Forde, Chris/Stuart, Mark/Simon, Joyce/Oliver, Liz/Valizade, Danat/Alberti, Gabriella/ Hardy, Kate/Trappmann, Vera/Umney, Charles/Carson, Calum, The Social Protection of Workers in the Platform Economy (fn. 10), p. 44; OECD, The Future of Social Protection: What Works for Non-Standard Workers? (fn. 11), p. 33.

93 Zachary, Kilhoffer/De Groen, Willem Pieter/Lenaerts, Karolien/Smits, Ine/Hauben, Harald/Waeyaert, Willem/Giacumacatos, Elisa/Lhernould, Jean-Philippe/Robin-Olivier, Sophie, Study to Gather Evidence on the Working Conditions of Platform Workers (fn. 9), p. 72.

94 Urzi Brancati, Maria Cesira/Pesole, Annarosa/Fernandez Macias, Enrique, New Evidence on Platform Workers in Europe (fn. 51), pp. 4, 26-27.

95 Does the Worker have a Say in the Platform Economy? The Time of Opportunities project, SAK, Autumn 2017, p. 8, https://www.ituc-csi.org/IMG/pdf/sak_finla nd_report_does-the-worker-have-a-say-in-the-platform-economy.pdf. Accessed 12 September 2020.

96 U. S. Bureau of Labor Statistics, Labor Force Statistics from the Current Population Survey, Electronically Mediated Employment (fn. 56). 
from home. ${ }^{97} \mathrm{~A}$ "strong difference by gender for those who could only 'work from home" in favour of women has been shown. ${ }^{98}$

(5) Platform work could be a stepping stone into a labour relationship, e.g. for the long-time unemployed..$^{99}$ Nearly half of those for whom platform work is a main source of income were unemployed for more than one year in the past five years. ${ }^{100}$

Researchers point out that, at the moment, there is a lack of knowledge as to whether there are any differences in motivation between those for whom platform work is a side job and those that generate their main income from platform work. ${ }^{101}$ Data contradicts the myth of student platform workers. The study by Huws et al. ${ }^{102}$ demonstrates that the proportion of students among crowdworkers is not higher than their general distribution in the labour force. In Berg's survey ${ }^{103}$ students make up 14.5 percent, and according to Serfling ${ }^{104}$ nine percent.

There are different reasons and factors that determine the choice of platform work as a main activity: type of platforms and platform work (e.g. high-skilled workers ${ }^{105}$ ), the relative difference between average incomes in the country of the client and the country of the worker. Berg discloses

97 Weißbuch "Arbeiten 4.0" - Antworten der BA auf die Herausforderungen der Digitalisierung, p. 13, https://www.bmas.de/SharedDocs/Downloads/DE/ThemaArbeitsmarkt/Arbeiten-4-0/stellungnahme-ba.pdf?_blob=publicationFile\&v=2. Accessed 12 September 2020; Joyce, Simon/Stuart, Mark/Forde, Chris/Valizade, Danat, Work and Social Protection in the Platform Economy in Europe (fn. 20), p. 21.

98 Digital Labour Platforms and the Future of Work: Towards Decent Work in the Online World (fn. 9), p. 38.

99 Forde, Chris/Stuart, Mark/Simon, Joyce/Oliver, Liz/Valizade, Danat/Alberti, Gabriella/Hardy, Kate/Trappmann, Vera/Umney, Charles/Carson, Calum, The Social Protection of Workers in the Platform Economy (fn. 10), p. $56 \mathrm{f}$.

100 Joyce, Simon/Stuart, Mark/Forde, Chris/Valizade, Danat, Work and Social Protection in the Platform Economy in Europe (fn. 20), p. 21.

101 Ibid., p. 20.

102 Huws, Ursula/Spencer, Neil H./Syrdal, Dag S./Holts, Kaire, Work in the European Gig Economy, FEPS/Uni Europa/Hertfordshire University, 2017, p. 37, https://u hra.herts.ac.uk/bitstream/handle/2299/19922/Huws_U._Spencer_N.H._Syrdal_D .S._Holt_K._2017_.pdf?sequence=2. Accessed 12 September 2020.

103 Berg, Janine, Income Security in the On-Demand Economy: Findings and Policy Lessons from a Survey of Crowdworkers (fn. 9), p. 5.

104 Serfling, Oliver, Crowdworking Monitor No. 1, in: Discussion Papers in Behavioral Sciences and Economics (2018) 4.

105 Freudenberg, Christoph, Rising Platform Work. Scope, Insurance Coverage and Good Practices among ISSA Countries (fn. 47), pp. 10-11. 
that motivations for platform work depend on the country of origin, e.g. Indian workers are more likely to rely on it as a source of main income while US workers consider it as secondary income. ${ }^{106}$

\section{Characteristics of Dependence}

\section{a) Dependence as a Legal Category}

From the social law perspective, the issue of "dependence" of platform workers is relevant for the employment classification for social law purposes, for the determination of the need for social protection as well as for the justification of the social responsibility of third persons who are not parties to the employment relationship.

Many researchers have referred to elements of dependence ${ }^{107}$ of platform workers. According to the prevalent opinion in the literature, platform workers are at least economically dependent. This dependence is often evidenced through new control and monitoring mechanisms on the part of platform providers. However, it has not been conclusively clarified whether a new manifestation of personal dependence or of economic dependence has emerged, or whether these are cases of a completely new dimension of dependence. Wiebke Brose, for example, speaks of a new form of dependence on the platform provider - which she describes as a subtype of economic dependence which is taking on a new quality due to digital control mechanisms. ${ }^{108}$

Because of the heterogeneity of platform workers and the various kinds of platform work and platforms, as well as because of different strategies concerning the allocation of tasks (allocated by the platform, by the client

106 Berg, Janine, Income Security in the On-Demand Economy: Findings and Policy Lessons from a Survey of Crowdworkers (fn. 9), p. 11.

107 Selzer, Dirk, Crowdworking - Arbeitsrecht zwischen Theorie und Praxis, in: Husemann, Tim/Wietfeld, Anne (eds.), Zwischen Theorie und Praxis - Herausforderungen des Arbeitsrechts. Dokumentation der 5. Assistententagung im Arbeitsrecht vom 16. - 17.07.2015, Bochum 2015, Baden-Baden: Nomos 2015, pp. 27-48; Waas, Bernd, Crowdwork in Germany, in: Waas, Bernd/Liebman, Wilma B./Lyubarsky Andrew/Katsutoshi, Kezuka (eds.), Crowdwork. A Comparative Law Perspective, Frankfurt am Main: Bund Verlag 2017, pp. 142-186.

108 Brose, Wiebke, Von Bismarck zu Crowdwork: Über die Reichweite der Sozialversicherungspflicht in der digitalen Arbeitswelt, in: Neue Zeitschrift für Sozialrecht, (2017) 1, p. 14. 
or by the worker), ${ }^{109}$ it is not possible to define one single pattern of dependence for either the platform provider or client(s). While platform workers are often similar to employees or economically dependent self-employed persons in some aspects, there are also aspects in which they are different. In my opinion, the new business model of platform work brings about a new type of dependence for the workers involved. When we try to identify the most salient features that characterise this new type of dependence in relation to platform workers, the following aspects are to be highlighted:

(1) Traditionally, economically dependent self-employed persons are dependent on a client. Platform workers can be dependent on a client as well as on the platform or on both. In the case of work on demand, economic and personal dependence exists predominantly in relation to the platform and not to certain clients. However, through rating and evaluation mechanisms clients are also involved in the exercise of control. It seems that in the case of crowdwork, sometimes the dependence on a client is higher than on a platform and not limited to ratings. There are findings that "clients often give detailed instructions on how to complete the work or directly supervise work execution and control the work processes"110.

(2) According to an assumption common until now in social law legislation, economically dependent self-employed persons typically work for one client or chiefly for one client. The idea behind the "one client criterion" was that if somebody works predominantly for one person, he or she cannot freely operate on the market given the extensive time commitment. The studies indicate that the majority of crowdworkers work for several clients. The abovementioned ILO study shows that eleven percent of freelancers have only one main client; 56 percent of them work with two to five different clients per month. ${ }^{111}$ Workers on demand have numerous clients.

109 Zachary, Kilhoffer/De Groen, Willem Pieter/Lenaerts, Karolien/Smits, Ine/Hauben, Harald/Waeyaert, Willem/Giacumacatos, Elisa/Lhernould, Jean-Philippe/Robin-Olivier, Sophie, Study to Gather Evidence on the Working Conditions of Platform Workers (fn. 9), p. 55.

110 Aleksynska, Mariya/Bastrakova, Anastasia/Kharchenko, Natalia, Work on Digital Labour Platforms in Ukraine: Issues and Policy Perspectives, International Labour Office - Geneva, ILO, 2018, p. 33.

111 Ibid., pp. 32-33. 
(3) A long-lasting relationship with a client serves as an indicator of economic dependence. ${ }^{112}$ Studies demonstrate the high volatility of platform workers. The relation with a client is rather short (especially in the case of micro tasks and work on demand) and the fluctuation rate of clients is high. However, the relation with a platform can be of long duration. During the course of such relationships platforms can influence participation in other platforms by high or low multihoming costs, or through dependence on ratings or reputation systems.

(4) Many platform workers participate in more than one platform. ${ }^{113}$

\section{b) Dependence Explored in Empirical Studies}

As has already been mentioned, many empirical studies consider "platform work" as a main job. Furthermore, they refer to "financial dependence on platform work". Some researchers differentiate between those platform workers who exclusively work on platforms and call them work-dependent platform workers, and those who have one or more jobs in addition to platform work and term the latter non-dependent platform workers. ${ }^{114}$ Other researchers use the term financial dependence to describe how much income is generated from platform work, ${ }^{115}$ and this term is also used in the study for the EMPL Committee. ${ }^{116}$ According to this study, 16 percent of the respondents - who were online platform workers (crowdworkers) - were heavily (more than 70 percent of their income comes from platform work) financially dependent on the platform economy, nine percent were highly (50-69 percent of income) and 13 percent were moderately (26-49 percent of income) financially dependent on platform work. Hereby, 68 percent of the respondents had one or multiple other jobs outside of the platform

112 Willemsen, Heinz Josef/Müntefering, Michael, Begriff und Rechtsstellung arbeitnehmerähnlicher Personen: Versuch einer Präzisierung, in: Neue Zeitschrift für Arbeitsrecht (NZA), 4 (2018), pp. 193-201, 195.

113 Leimeister, Jan Marco/Durward, David/Zogaj, Shkodran, Crowd Worker in Deutschland. Eine empirische Studie zum Arbeitsumfeld auf externen Crowdsourcing-Plattformen, Study 323, Hans Böckler Stiftung, p. 31, https://www.boec kler.de/pdf/p_study_hbs_323.pdf. Accessed 12 September 2020.

114 Joyce, Simon/Stuart, Mark/Forde, Chris/Valizade, Danat, Work and Social Protection in the Platform Economy in Europe (fn. 20), p. 20.

115 Forde, Chris/Stuart, Mark/Simon, Joyce/Oliver, Liz/Valizade, Danat/Alberti, Gabriella/Hardy, Kate/Trappmann, Vera/Umney, Charles/Carson, Calum, The Social Protection of Workers in the Platform Economy (fn. 10), p. 48.

116 Ibid. 
economy. ${ }^{117}$ The COLLEEM I study came to the result that 2.3 percent of the European working-age population in 14 Member States earned 50 or more percent of their income via platforms (both crowdwork and work on demand). ${ }^{118}$ However, the recent COLLEEM II study showed a decline of the number of such persons to 1.4 percent (a drop of 0.9 percent). ${ }^{119} \mathrm{Si}$ multaneously, this study indicates a small increase of platform work as a side job. ${ }^{120}$

Workers with a stable job outside the platform economy have higher income security than those who rely on their platform earnings. ${ }^{121}$ Highskilled workers may use platform work to supplement their income. Lowskilled workers without a permanent job are likely to become more dependent on platform work as their primary source of income. ${ }^{122}$ For these groups of platform workers also organisational and algorithmic dependency on platforms has been demonstrated and their need for social protection is comparable with that of employees. Studies show an interrelation between dependencies on platform work or on platforms and the need for social protection coverage of platform workers. The study for the European Commission outlines that "those who depend the most on platform work are covered the least" 123 .

117 Ibid.

118 Pesole, Annarosa/Urzí Brancati, Maria Cesira/Fernández-Macías, Enrique/Biagi, Federico/González Vázquez, Ignacio, Platform Workers in Europe (fn. 5), p. 3.

119 Urzi Brancati, Maria Cesira/Pesole, Annarosa/Fernandez Macias, Enrique, New Evidence on Platform Workers in Europe (fn. 51), p. 3.

120 Ibid.

121 Zachary, Kilhoffer/De Groen, Willem Pieter/Lenaerts, Karolien/Smits, Ine/Hauben, Harald/ Waeyaert, Willem/Giacumacatos, Elisa/Lhernould, Jean-Philippe/RobinOlivier, Sophie, Study to Gather Evidence on the Working Conditions of Platform Workers (fn. 9), p. 75.

122 Forde, Chris/Stuart, Mark/Simon, Joyce/Oliver, Liz/Valizade, Danat/Alberti, Gabriella/Hardy, Kate/Trappmann, Vera/Umney, Charles/Carson, Calum, The Social Protection of Workers in the Platform Economy (fn. 10), p. 48; Zachary, Kilhoffer/De Groen, Willem Pieter/Lenaerts, Karolien /Smits, Ine/Hauben, Harald/ Waeyaert, Willem/Giacumacatos, Elisa/Lhernould, Jean-Philippe/Robin-Olivier, Sophie, Study to Gather Evidence on the Working Conditions of Platform Workers (fn. 9), p. 72; Conen, Wieteke/Schippers, Joop, Self-Employment: Between Freedom and Insecurity, in: Conen, Wieteke/Schippers, Joop, Self-Employment as Precarious Work. A European Perspective, Cheltenham: Edward Elgar Publishing 2019, p. 7.

123 Zachary, Kilhoffer/De Groen, Willem Pieter/Lenaerts, Karolien/Smits, Ine/Hauben, Harald/Waeyaert, Willem/Giacumacatos, Elisa/Lhernould, Jean-Philippe/Robin-Olivier, Sophie, Study to Gather Evidence on the Working Conditions of Platform Workers (fn. 9), p. 72. 
We can assume that financial dependency on platform work might indicate a new pattern of dependence in comparison to the well-known legal construction of economic dependency of dependent self-employed workers on the principal/(main) client. However, this is rather a sign of the vulnerability of workers and a reflection of the labour fragmentation which is characteristic also for other types of non-standard work (e.g. on-call work, zerohours contracts). Workers just struggle to accumulate orders from different platforms in order to make ends meet, especially if such a kind of employment is their main activity. The category of financial dependence on platform work explored in empirical studies is not suitable to justify the classification of platform workers as employees and to justify social responsibility of platforms over workers; it is only a socio-economic characteristic of platform workers.

Interestingly, this study simultaneously outlines that "self-employed platform workers who are economically dependent on a single platform [...] appear to be the most vulnerable and least protected by [...] social protection legislation at both national and EU level" ${ }^{124}$. It confirms the rationale and legitimacy of the already existing strategy of imposing social insurance responsibility on the (main) client for dependent self-employed contractors as this is provided for in the social legislation of some European countries. ${ }^{125}$

\section{Access of Platform Workers to Social Protection}

The general outcome of the different studies is evidence of a low level of access to social protection of platform workers, especially those for whom it is a main job. Insurance coverage differs significantly if platform work is carried out as a side job. Those for whom platform work is a side activity rely on social protection from salaried employment. ${ }^{126}$

124 Ibid.

125 Chesalina, Olga, Extending Social Security Schemes for "Non-Employees": A Comparative Perspective, in: Zeitschrift für ausländisches und internationales Arbeits- und Sozialrecht, (2020) 1, pp. 3-12.

126 Zachary, Kilhoffer/De Groen, Willem Pieter/Lenaerts, Karolien /Smits, Ine/Hauben, Harald/ Waeyaert, Willem/Giacumacatos, Elisa/Lhernould, Jean-Philippe/RobinOlivier, Sophie, Study to Gather Evidence on the Working Conditions of Platform Workers (fn. 9), p. 26 and p. 72; Garben, Sacha, Protecting Workers in the Online Platform Economy: An Overview of Regulatory and Policy Developments in the EU, European Agency for Safety and Health at Work, Luxembourg: Publications Office of the European Union, 2017, https://osha.europa.eu/fr/publi 
The study by Joyce et al. demonstrates that between 68 percent and 82 percent of micro task platform workers (for whom it is a main job) had no access to the different branches of social protection with the exception of healthcare. ${ }^{127}$ Berg's study of 2016 indicates that 90.6 percent of crowdworkers (AMT workers in the US) did not contribute to social security ${ }^{128}$ (in the US reality this is equivalent to not having access to social protection). This situation calls forth concerns among platform workers about their social security and accident insurance in particular. ${ }^{129}$

Those who carry out platform work as a main job are much less likely to be saving towards a pension - being the case for less than one in five than those that carry out platform work as a side activity. ${ }^{130}$ The study for the EMPL Committee (without specification as to which kind of platform work is considered - main or side job) reveals that only just over a third of micro task platform workers ( 35.5 percent) were paying into a personal pension. ${ }^{131}$ Concerning access to different social benefits, this study reported that 22.6 percent of all platform workers have no access to healthcare, 47 percent - to sickness benefits, 60.6 - disability, 58.1 percent - old age, 69.5 - pregnancy, 63.1 percent - unemployment benefits. ${ }^{132}$ This is a very interesting outcome which shows that "workers who were relatively heavily dependent on platform work were only marginally disadvantaged in

cations/protecting-workers-online-platform-economy-overview-regulatory-and-p olicy-developments; Berg, Janine, Income Security in the On-Demand Economy: Findings and Policy Lessons from a Survey of Crowdworkers (fn. 9), p. 16; Eurofound, Employment and Working Conditions of Selected Types of Platform Work (fn. 9), p. 19; Pesole, Annarosa/Urzi Brancati, Maria Cesira/Fernández-Macías, Enrique/Biagi, Federico/González Vázquez, Ignacio, Platform Workers in Europe (fn. 5).

127 Joyce, Simon/Stuart, Mark/Forde, Chris/Valizade, Danat, Work and Social Protection in the Platform Economy in Europe (fn. 20), p. 25.

128 Berg, Janine, Income Security in the On-Demand Economy: Findings and Policy Lessons from a Survey of Crowdworkers (fn. 9).

129 Zachary, Kilhoffer/De Groen, Willem Pieter/Lenaerts, Karolien/Smits, Ine/Hauben, Harald/Waeyaert, Willem/Giacumacatos, Elisa/Lhernould, Jean-Philippe/Robin-Olivier, Sophie, Study to Gather Evidence on the Working Conditions of Platform Workers (fn. 9), p. 72.

130 Joyce, Simon/Stuart, Mark/Forde, Chris/Valizade, Danat, Work and Social Protection in the Platform Economy in Europe (fn. 20), pp. 22, 25.

131 Forde, Chris/Stuart, Mark/Simon, Joyce/Oliver, Liz/Valizade, Danat/Alberti, Gabriella/Hardy, Kate/Trappmann, Vera/Umney, Charles/Carson, Calum, The Social Protection of Workers in the Platform Economy (fn. 10), p. 57.

132 Ibid.; Florisson, Rebecca/Mandl, Irene, Platform Work: Types and Implications for Work and Employment - Literature Review (fn. 14), p. 99. 
terms of access to social protection, compared with occasional platform workers". ${ }^{133}$ This means that for a significant number of workers who have another source of income, their other source(s) may come from other forms of insecure, non-standard employment or self-employed work, ${ }^{134}$ which would also explain their limited access to social protection, especially to unemployment benefits and sickness benefits. ${ }^{135}$ The ILO study of 2018 confirms that of crowdworkers engaged in other paid jobs, 33 percent were in non-standard employment, including part-time and casual work, and 25 percent were freelancers. ${ }^{136}$ However, we have to keep in mind that many studies first of all represent the situation of micro task platform workers, ${ }^{137}$ who are mostly unskilled or low-skilled, and we cannot transfer these results to the entirety of platform workers. Taking the German example, the study by Leimeister has shown that more than 50 percent of workers who carry out mostly unskilled and low-skilled "micro tasks" (which proved to be particularly precarious) are not insured in a pension scheme at all. ${ }^{138}$

However, platform workers differ significantly from each other in terms of income; dependence on platform work and their access to social protection. For instance, the study by Bertscheck et al. ${ }^{139}$ has shown that in Germany, in 2016, about 44 percent of crowdworkers were included in a private pension scheme; 85 percent were insured in statutory health insurance, eight percent got social benefits in terms of unemployment benefits, social assistance and social welfare benefits.

A very important outcome of the research by Freudenberg is that in two thirds of the 30 ISSA members, additional income from platform work as a

133 Forde, Chris/Stuart, Mark/Simon, Joyce/Oliver, Liz/Valizade, Danat/Alberti, Gabriella/Hardy, Kate/Trappmann, Vera/Umney, Charles/Carson, Calum, The Social Protection of Workers in the Platform Economy (fn. 10), p. 64.

134 Ibid., p. 55.

135 Ibid., p. 65.

136 Digital Labour Platforms and the Future of Work: Towards Decent Work in the Online World (fn. 9), p. 42.

137 E.g. the study by Forde et al. (fn. 10), p. 11 is based on an original survey of 1,200 micro task platform workers across four established platforms: AMT, Clickworker, CrowdFlower and Microworkers.

138 Leimeister, Jan Marco/Durward, David/Zogaj, Shkodran, Crowd Worker in Deutschland. Eine empirische Studie zum Arbeitsumfeld auf externen Crowdsourcing-Plattformen (fn. 113).

139 BMAS, Befragung zum sozioökonomischen Hintergrund und zu den Motiven von Crowdworkern, Forschungsbericht 462, 2016, http:/www.bmas.de/SharedD ocs/Downloads/DE/PDF-Publikationen/Forschungsberichte/fb-462-endbericht-cr owdworker.pdf?_blob=publicationFile\&v=4. Accessed 12 September 2020. 
side job is not taken into consideration for social security purposes. ${ }^{140}$ This can be explained by different reasons: legislation does not provide for the coverage of extra income at all or merely below a certain threshold; platform work is carried out informally. ${ }^{141}$

\section{Comparison of the Situation concerning Access to Social Protection of Platform Workers and Non-Standard Workers, and that of Self-Employed Persons}

As already indicated in the Introduction, studies that analyse the situation of platform workers are divided into two main groups: One group of research is dedicated exclusively to platform workers. The other group of studies investigates the situation of platform workers within the broader categories of "non-standard employed" or "self-employed". Many studies point out that one of the most important factors that explains the limited access of platform workers to social protection is their classification as selfemployed workers. ${ }^{142}$ The challenges for the social protection of platform workers are regarded to be the same as the challenges for persons in other non-standard forms of employment and self-employed persons. Therefore, it has been proposed to improve the social protection of self-employed and non-standard workers in general, not only that of platform workers. ${ }^{143}$

Despite the fact that there are many similar challenges concerning access to social protection among these groups, caution is advised concerning the automatic transfer of the outcomes. Research points out that in order to answer whether we need a special tailor-made solution for platform workers or rather solutions for all atypical employees or self-employed workers in total, it is necessary to compare the coverage of social security

140 Freudenberg, Christoph, Rising Platform Work. Scope, Insurance Coverage and Good Practices among ISSA Countries (fn. 47), p. 18.

141 Ibid.

142 Zachary, Kilhoffer/De Groen, Willem Pieter/Lenaerts, Karolien/Smits, Ine/Hauben, Harald/Waeyaert, Willem/Giacumacatos, Elisa/Lhernould, Jean-Philippe/Robin-Olivier, Sophie, Study to Gather Evidence on the Working Conditions of Platform Workers (fn. 9), p. 71.

143 Ibid., p. 71. Piasna, Agnieszka, Counting Gigs. How Can we Measure the Scale of Online Platform Work? (fn. 6), p. 17; Aleksynska, Mariya/Bastrakova, Anastasial Kharchenko, Natalia, Work on Digital Labour Platforms in Ukraine: Issues and Policy Perspectives (fn. 110); Berg, Janine, Income Security in the On-Demand Economy: Findings and Policy Lessons from a Survey of Crowdworkers (fn. 9). 
in the entire working population at the same time. ${ }^{144}$ This is the only way to assess whether they have particular deficiencies in access to social security and in the financing of social security. ${ }^{145}$

While platform work is mostly considered de jure as self-employment, it is interesting to compare the development of platform work with the development of self-employment in the appropriate country. On the one hand, official statistics and studies do not show an increase of self-employment taking place in general. ${ }^{146}$ The studies show a steady decrease in the share of self-employed persons in Bulgaria, Ireland, Italy, Lithuania, Poland, Romania, Switzerland, Hungry and Portugal. On the contrary, in the UK, Netherlands and Slovakia, a substantial increase of self-employment can be observed. ${ }^{147}$ Nevertheless, there are some new tendencies concerning self-employment: firstly, the number of self-employed persons with employees has fallen; ${ }^{148}$ secondly, there are changes in motivation among the self-employed - for every fifth, this form of employment is involuntary; ${ }^{149}$ thirdly, there is a rise in part-time self-employment while historically this form of self-employment has been the exception. ${ }^{150}$

On the other hand, it remains unclear whether platform workers are to be counted among the self-employed. ${ }^{151}$ While the classification of "selfemployed" should be the result of a legal review, in some studies, for example in the labour force studies, the employment classification is based on the subjective view of the interviewed person ${ }^{152}$ with the result that -

144 Cf. BMAS, Plattformbasierte Erwerbsarbeit: Stand der empirischen Forschung (fn. 62), p. 22.

145 Ibid.

146 There are different reasons that can explain an increase or decrease in self-employment. For example, the fall in numbers of self-employed workers in the UK in the late 1990s was the result of a reclassification of some workers in the construction industry. See Choonara, Joseph, Insecurity, Precarious Work and Labour Markets, Cham: Palgrave Macmillan 2019, p. 113.

147 Schippers, Joop, Labour Market Flexibility, Self-Employment and Precariousness, in: Conen, Wieteke/Schippers, Joop, Self-Employment as Precarious Work. A European Perspective, Cheltenham: Edward Elgar Publishing 2019, p. 30.

148 Joyce, Simon/Stuart, Mark/Forde, Chris/Valizade, Danat, Work and Social Protection in the Platform Economy in Europe (fn. 20), p. 18.

149 Ibid.

150 Choonara, Joseph, Insecurity, Precarious Work and Labour Markets (fn. 146), p. 113.

151 Joyce, Simon/Stuart, Mark/Forde, Chris/Valizade, Danat, Work and Social Protection in the Platform Economy in Europe (fn. 20), p. 18.

152 Choonara, Joseph, Insecurity, Precarious Work and Labour Markets (fn. 146), p. 113. 
for example in the study of Pesole et al. - 68.1 percent of platform workers claimed to be employees. ${ }^{153}$

Taking into account the result that platform work is carried out as a side job, it would be very important to compare the access to social protection of side platform workers with workers in other forms of non-standard work and self-employment also carried out as a secondary job. However, until now little is known about non-standard employment and self-employment as a side job as studies and labour force surveys predominantly focus on a main occupation. This information is easier to find in the national reports than in cross-national studies. According to one opinion, having a side job can indicate a reduction in standard employment. ${ }^{154}$ However, the rate of persons with a second job in the EU is rather low (about four percent) and stable. ${ }^{155}$ Eurofound demonstrates that according to data from the sixth European Working Conditions Survey nine percent of the self-employed without employees have another job. ${ }^{156}$ However, these studies probably do not reflect the situation in certain European countries. For example, in France at the end of 2016, 23 percent of self-employed persons were also employees or used to be employees during the year. These averages reveal very different situations: half of the persons involved in pluriactivity have a main activity, whether as employees or selfemployed persons, from which they earn a large income as compared to other self-employed persons with a less lucrative additional activity. The other persons involved in pluriactivity have both quite low self-employed incomes and wages: they often have intermittent activities or have just launched their business. ${ }^{157}$ For example, the German study concerning self-employed gainful activity demonstrates that almost one third of all self-employed in Germany are working part-time; hereby, the share of selfemployed persons with a side job is only 6 percent. ${ }^{158}$ On the contrary, the

153 Pesole, Annarosa/Urzi Brancati, Maria Cesira/Fernández-Macías, Enrique/Biagi, Federico/González Vázquez, Ignacio, Platform Workers in Europe (fn. 5), p. 4.

154 Joyce, Simon/Stuart, Mark/Forde, Chris/Valizade, Danat, Work and Social Protection in the Platform Economy in Europe (fn. 20), p. 17.

155 Ibid.

156 Eurofound, Exploring Self-Employment in the European Union, Publications Office of the European Union, Luxembourg, 2017, p. 9.

157 One in four self-employed people also works as an employee. Cf. Guilhem, Théron, The French National Institute for Statistics (Insee), https://www.insee.fr/ en/statistiques/4280464. Accessed 12 September 2020.

158 Conen, Wieteke/Schippers, Joop/Schulze Buschoff, Karin, Self-Employed without Personnel between Freedom and Insecurity, Hans-Boeckler-Foundation, Study No. 5, August 2016, pp. 30-31. 
study of Bertelsmann Stiftung shows that 99 percent of platform workers in Germany carry out such an activity as a side job, and at the same time have better social protection. ${ }^{159}$

First insights demonstrate that platform workers differ significantly from each other in terms of income and that the spread of the household income among digital self-employed workers is even greater than among the "classic" self-employed. ${ }^{160}$ Furthermore, some research and studies show that online platform work also poses new (and worse) health and safety risks and that offline platform work goes along with higher injury rates than other non-standard arrangements. ${ }^{161}$

\section{Implications for Social Security from Practical Evidence}

Concerning the social responsibility of platform operators, practice demonstrates a deep contradiction between their alleged position as an intermediary and their factual reaction to the social risks of platform workers, which demonstrates that platforms acknowledge their responsibility for some social risks. ${ }^{162}$

The study of the European Social Insurance Platform demonstrates that "Uber gives drivers and couriers across Europe a one-off childbirth allowance of 1,000 euros. The benefit is granted under the following conditions: Uber drivers must have completed 150 trips and Uber Eats couriers 30 deliveries in the two months prior to the birth of the child. In addition, Uber gives drivers and couriers across Europe a sickness or injury compensation for a maximum of 30 days on-trip and 15 days off-trip of varying amounts according to the country [...] The same conditions apply to this benefit as to the maternity or paternity benefit. In case of accidents while

159 Baethge, Catherine Bettina/Boberach, Michael/Hoffmann, Anke/Wintermann, Ole, Plattformarbeit in Deutschland, Bertelsmann Stiftung, 2019, https://www.bertels mann-stiftung.de/fileadmin/files/BSt/Publikationen/GrauePublikationen/Plattfo rm_07lay.pdf, p. 6, Accessed 12 September 2020.

160 Leimeister, Jan Marco/Durward, David/Zogaj, Shkodran, Crowd Worker in Deutschland. Eine empirische Studie zum Arbeitsumfeld auf externen Crowdsourcing-Plattformen (fn. 113), p. 43.

161 Garben, Sacha, Tackling Social Disruption in the Online Platform Economy. Shifting the Narrative to the Benefits of (EU) Regulation (fn. 24), p. 5.

162 Fairwork, The Gig Economy and Covid-19: Looking Ahead, Oxford, United Kingdom, 2020, p. 3. 
working causing permanent disability Uber gives drivers and couriers across Europe a compensation. All of the above is provided by AXA"163.

Also, other platform operators have insured their workers on demand (couriers, drivers) against accidents at work. For example, Yandex.Taxi in Russia has insured all rides from 1 January 2017. According to the information on the Yandex.Taxi website, in case of a car accident during transportation the client and the driver can claim damages for harm caused to life and health. The maximum amount of compensation is two million roubles. ${ }^{164}$ Deliveroo offers its couriers "a scheme through private insurers that gives its riders accident insurance against medical expenses and loss of earnings". ${ }^{165}$

The COVID-19 pandemic has imposed on workers on demand (couriers, drivers etc.) immense risks to health and life. At the beginning of the pandemic, platforms refused to provide any social benefits to platform workers due to their status of "self-employed"/"independent contractors". ${ }^{166}$ The strong pressure from regulators, driver's advocates and the media has forced platforms to respond to the health risk caused by COVID-19. Many platforms, especially those that provide ride-hailing services, have introduced regulations concerning sickness payments for platform workers e.g. Uber, on 7 March 2020, launched a global financial assistance policy for drivers diagnosed with COVID-19; on 15 March 2020 and on 17 April 2020, the scope of the regulation was extended to drivers required to self-isolate. ${ }^{167}$ In fact, the conditions for individual payment are similar to the conditions for payment on the part of an employer to an employee of continued remuneration in case of temporary incapacity to work - cf. the eligibility conditions (waiting period) - at least one trip in the 30 days before the application for assistance; calculation of payment - average

163 ESIP, Are Social Security Systems Adapted to New Forms of Work Created by Digital Platforms? (fn. 15), p. 27.

164 Yandex homepage, https://yandex.ru/support/taxi/insurance.html. Accessed 12 September 2020.

165 ESIP, Are Social Security Systems Adapted to New Forms of Work Created by Digital Platforms? (fn. 15), p. 28, also Zachary, Kilhoffer/De Groen, Willem Pieter/ Lenaerts, Karolien/Smits, Ine/Hauben, Harald/Waeyaert, Willem/Giacumacatos, Elisa/Lhernould, Jean-Philippe/Robin-Olivier, Sophie, Study to Gather Evidence on the Working Conditions of Platform Workers (fn. 9), p. 122.

166 Fairwork, The Gig Economy and Covid-19: Looking Ahead (fn. 162), p. 13.

167 Katta, Srujana/Badger, Adam/Graham, Mark/Howson, Kelle/Ustek-Spilda, Fundal Bertolini, Alessio, (Dis)embeddedness and (De)commodification: COVID-19, Uber, and the Unravelling Logics of the Gig Economy, in: Dialogues in Human Geography, 10 (2020) 2, p. 205. 
weekly earnings over the three months before the application; the maximum amount of payment - for up to 14 days. ${ }^{168}$

If platform companies, in fact, act only as a marketplace, there is no reason to provide for insurance against accidents at work, sickness payments or maternity benefits. They did indeed, de facto, admit responsibility for different social risks. It does not matter whether they decided in favour of such regulations voluntarily or rather involuntary as, for example, a reaction to the COVID-19 crisis.

\section{Conclusion}

Numerous studies have already been dedicated to the measuring of platform work and its characteristics. The issues of social security of platform workers is still quite a young research field both in empirical studies and social law research. The main goal of this chapter is to find out implications for social security from empirical findings and practical evidence. Great insights have already been gained from empirical studies concerning the social protection of platform workers. The most important finding confirmed in all existing studies is that platform work is mainly carried out as a side job in addition to one or several other jobs. However, those who carry out low-qualified platform work as a main job, and especially for one single platform, are protected the least against social risks. To conclude, the following outcomes shall be stressed and proposals for future investigations be made.

1. The empirical studies provide a lot of information about the socio-demographical characteristics of platform workers, their working conditions, access to labour and social protection. However, careful attention must be paid when interpreting the figures and trends from such empirical research on platform work due to its numerous shortcomings.

2. The problem is that a large part of cross-national studies ${ }^{169}$ represent the situation of crowdworkers and especially low-skilled micro taskers,

168 https://www.uber.com/en-BH/blog/update-covid-19-financial/. Accessed 12 September 2020.

169 Berg, Janine, Income Security in the On-Demand Economy: Findings and Policy Lessons from a Survey of Crowdworkers (fn. 9); Digital Labour Platforms and the Future of Work: Towards Decent Work in the Online World (fn. 9); Forde, Chris/Stuart, Mark/Simon, Joyce/Oliver, Liz/Valizade, Danat/Alberti, Gabriella/ Hardy, Kate/Trappmann, Vera/Umney, Charles/Carson, Calum, The Social Protection of Workers in the Platform Economy (fn. 10). 
who can be more easily captured by online research than workers on demand. Hereby, a significant part of the studies is based on research (surveys and interviews) of the American platform AMT. Caution is advised as regards the extrapolation of outcomes in relation to dependence patterns and access to social security from crowdworkers to other groups of platform workers (e.g. workers on demand, high-skilled workers) and to other countries with differing systems of social security.

3. We share the opinion ${ }^{170}$ that for answering the question of how to address the challenges of social protection for platform workers - whether through a special tailor-made solution for platform workers (or even special groups of platform workers) or rather through solutions that address all non-standard workers - it is necessary to compare the formal and effective coverage of social security in the entire working population at the same time, and to find out whether there are special problems and gaps in access to social protection for platform workers.

4. Even if many challenges related to platform work are similar to the challenges of non-standard employment and self-employment, the heterogeneity of platform workers and the fact that platform work is chiefly carried out as a side job - which is not typical for the self-employed - should be taken into account. Further investigation concerning the "main" job situation of side platform workers is welcomed. In particular, it would be interesting whether the main job is carried out in self-employment or salaried employment and, if the latter is the case, what kind of salaried employment it is.

5. It is interesting that studies consider as a "main job" of platform workers not work for one single platform, but platform work as a kind of work what is typical for empirical studies exploring self-employment.

6. The category of financial dependence on platform work as explored in empirical studies is not suitable for justifying the classification of platform workers as employees and for justifying social responsibility of platforms for workers; it is only a socio-economic characteristic of platform workers that reflects labour fragmentation, which is characteristic also of other types of non-standard work.

7. The patterns of personal and economic dependence of persons who provide services via online labour platforms of platform providers or clients should be further investigated. This research can assist the inves-

170 BMAS. Plattformbasierte Erwerbsarbeit: Stand der empirischen Forschung (fn. 60), p. 22. 
tigations as to who controls the activity of platform workers and whether platform providers are responsible for the service providers and, hence, whether their participation in the financing of social protection for the service providers would be justified.

8. In the past years, it has become a matter of scientific debate whether platform providers - or clients respectively - have to bear their share of social (financial) responsibility towards contractors (whose labour force might even be used to dump prices) and towards the state. To date, and especially since the coronavirus crisis, many examples are known from practice demonstrating that platforms are taking on responsibility for social risks (work accident, sickness, childbirth) of workers on demand concluding agreements with private insurance companies for the benefit of such workers. This demonstrates a deep contradiction between the alleged position of platforms as intermediaries and their factual reaction to the social risks of workers on demand. On the one hand, the assumption of responsibility by platforms - both voluntarily and undertaken under public pressure - should be explored in further research. Hereby, the changes of the platform operator's policy (extending or reducing its social insurance responsibility) in the course of time should be investigated. A very interesting case is presented in the form of insurance schemes dedicated to platform workers by AXA insurance company.

9. In some countries, social responsibility on the part of platforms in relation to platform workers has already been established in the legislation (e.g. in France). Many platforms in France have launched partnerships with private insurance companies for accident and liability protection of platform workers. ${ }^{171}$ In other countries, some platforms have undertaken such steps voluntarily. It would be very interesting to get more empirical evidence in relation to enforcement aspects, the level of protection guaranteed and the allocation of costs between platforms and platform workers.

10. Up to date, there is a lack of statistical and empirical data concerning the share of informal (undeclared) platform work. This information is very important not only for the correct estimation of the real size of the platform economy. From the point of view of social security, this information can help to prevent fraud related to the receipt of social assis-

171 See Kessler, Francis, Social Security in the Platform Economy: The French Example - New Actors, New Regulations, Old Problems, Chapter 11, Section III, p. 270 in this book. 
tance benefits from the state (e.g. in cases where a worker pretends to be unemployed, as platform work is not exactly regulated and often is not seen as "work"). The reviewed persons should be asked whether they are unemployed and whether they are receiving unemployment benefits and social assistance benefits. 